\title{
Isolation of Lipase Producing Fungi from Palm Oil Mill Effluent (POME) Dump Sites at Nsukka
}

\author{
Charles Ogugua Nwuche* and James Chukwuma Ogbonna \\ Department of Microbiology; University of Nigeria; Nsukka; Enugu State - Nigeria
}

\begin{abstract}
In this study, twelve fungal lipase producing strains belonging to Aspergillus, Penicillium, Trichoderma and Mucor genera were isolated from palm oil mill effluent composts. The Aspergillus spp. were more frequent (42\%) and was present in all the samples assayed. Mucor sp. was the least encountered (8.3\%).The lipase producing profile showed that Trichoderma (8.07-8.24 u/mL) and Aspergillus (6.25 -7.54 u/mL) spp. were the highest lipase producers while Mucor $(5.72 \mathrm{u} / \mathrm{mL})$ was the least.
\end{abstract}

Key words: Enzymes, Lipases, Triglycerides, Esterification, Waste water treatment

\section{INTRODUCTION}

Lipases (triacylglycerol acylhydrolases, EC 3.1.1.3) are a class of enzymes that catalyze the hydrolyses of long chain triglycerides to intermediate and short chain di and mono glycerides, free fatty acids and glycerol (Prazeres et al., 2006; Babu and Rao, 2007). Apart from hydrolyses, lipases are also involved in a wide range of conversion reactions that include esterification, interesterification, transesterification, alcoholysis, acidolysis and aminolysis in non aqueous media (Davranov, 1994; Savitha et al., 2007). Lipase mediated reactions are reversible, hence, the enzyme can catalyze the esterification of glycerol from mono, di and triglycerides. This versatility makes lipases the enzyme of choice for potential applications in the food, detergent, pharmaceutical, leather, textile, cosmetic and paper industries (Houde et al., 2004).
Lipases are widely distributed in nature and have been found in many species of animals, plants, bacteria, yeasts and fungi (Saeed et al., 2005).Indeed, lipases from a large number of sources have been purified to homogeneity (Saxena et al., 2003). Such lipases from different origins differ widely in physical and biochemical properties such as positional specificity, fatty acid specificity, thermo stability and optimum $\mathrm{pH}$. (Saeed et al., 2005; Kyu et al., 2005). Microbial enzymes are often more useful than enzymes derived from plants and animals because of the great variety of catalytic activities available, the high possible yields, ease of genetic manipulation, regular supply due to absence of seasonal fluctuations and rapid growth of microorganisms on inexpensive media (Davranov, 1994) Microbial enzymes are also more stable and safer than their corresponding plant and animal enzymes and their production is more convenient (Wiseman, 1995).

Microbial lipases have already established their vast potential regarding usage in numerous

*Author for correspondence: charlesnwuche@yahoo.com 
applications. Specifically, they are employed in waste water treatment (degreasing of lipid clogged drains), pharmaceutical (resolution of racemic mixtures), dairy (hydrolysis of milk, fat), leather (removal of lipids from hides and skin), detergent (removal of oil / fat stains) and medical (diagnostic tool in blood triglyceride assay) industries (Davranov, 1994; Jaeger and Reetz, 1998; Pandey et al., 1999 ; Rathi et al., 2001; Burkert et al., 2004; Kumar, 2005).

Bacterial strains are generally more used as sources of lipases because they offer higher activities compared to yeast (Frost and Moss, 1987). Fungal lipases which are reported to be derived mainly from Candida and Aspergillus sp (Savitha and Ratledge, 1991) and Geotrichum sp. (Ginalska et al., 2004) are particularly important in industrial applications (Essamri et al., 1998).

Because of the numerous potential uses of lipase enzyme, this study was undertaken to isolate and identify lipase producing microorganisms.

\section{MATERIALS AND METHODS}

\section{Sample Collection:}

Soil samples were collected from four different palm oil mill effluent (POME) dumpsites at Nsukka, Enugu State, Nigeria. Samples were taken from a depth of $2-5 \mathrm{~cm}$, transported in sterile plastics bags and stored at $4^{0} \mathrm{C}$ when not used immediately.

\section{Isolation of Lipase Producing Microorganisms:}

Ten gram samples (from each site) were suspended in $250 \mathrm{~mL}$ Erlenmeyer flask containing $100 \mathrm{~mL}$ sterile physiological saline (PS; Oxoid). This was followed by constant and vigorous stirring for $30 \mathrm{mins}$ at $120 \mathrm{rpm}$ to dislodge soil clumps before allowing settling. The supernatant was decanted and a 10-fold serial dilution made from it. Approximately, $100 \mu \mathrm{L}$ of each dilution $\left(10^{-2}-10^{4}\right)$ was spread inoculated on a mineral salts agar medium formulated by a modification of the methods of Kashmiri et al., (2006) and Bapiraju et al., (2004). The medium contained (g /l) palm oil 10 (emulsified in Tween 80 at $10 \mathrm{~mL}$ oil: $1 \mathrm{~mL}$ Tween); $\left(\mathrm{NH}_{4}\right)_{2} \mathrm{SO}_{4}, 5 ; \mathrm{Na}_{2} \mathrm{HPO}_{4}, 6$; $\mathrm{KH}_{2} \mathrm{PO}_{4}, 2 ; \mathrm{MgSO}_{4}, 3 ; \mathrm{CaCl}_{2}, 3$ and Agar 12. The $\mathrm{pH}$ of the medium was adjusted to 5.0 using citrate-phosphate buffer $(0.5 \mathrm{M})$. Plates were incubated at $28{ }^{\circ} \mathrm{C}$ for $5-7$ days and checked every day for growth.
Developed colonies were purified and transferred to the mineral salts agar slants for storage. In addition, fungal colonies were subcultured on Potato Dextrose Agar (PDA, Oxoid) plates for macro and micro-morphological identification.

\section{Lipase Production}

Suspensions of mature spores were obtained by gently washing the surface of agar slants with $5 \mathrm{~mL}$ of sterile saline and the resulting suspension adjusted to $10^{6}$ spores $/ \mathrm{mL}$ in a Neubeur haemacytometer before transferring $5 \mathrm{~mL}$ of the diluted spore suspension into $250 \mathrm{~mL}$ Erlenmeyer flask containing $45 \mathrm{~mL}$ of the mineral salts medium without agar. The flasks were incubated at $28^{\circ} \mathrm{C}$ for $72 \mathrm{hr}$ at $100 \mathrm{rpm}$. The culture broth was then filtered in a double layered muslin cloth followed by Whatman No. 1 filter paper. The filtrate was used as the crude enzyme source.

\section{Assay of Lipase Activity}

Lipase activity was measured by modification of the titrimetric assay method of Pignede et al., (2000). The substrate (primary) emulsion was prepared with olive oil, gum arabic and water (4:1:2).Appropriate measure of olive oil and gum arabic was triturated with pestle in a clean dry porcelain mortar. When well mixed, the vehicle (water) was added all at once and triturated vigorously to produce a thick white creamy emulsion; the primary emulsion. The supernatant of the cell culture $(20 \mu \mathrm{L})$ was added to $5 \mathrm{~mL}$ of substrate emulsion and $2 \mathrm{ml}$ of $50 \mathrm{mM}$ phosphate buffer, $\mathrm{pH} \quad 7.0 \quad\left(\mathrm{Na}_{2} \mathrm{HPO}_{4}-\mathrm{KH}_{2} \mathrm{PO}_{4}\right)$ before incubating for $20 \mathrm{mins}$ at $37^{\circ} \mathrm{C}$ with shaking (120rpm).The reaction was stopped with $4 \mathrm{~mL}$ of acetone-ethanol $(1: 1 \mathrm{v} / \mathrm{v})$ containing 2-3drops of $0.09 \%$ thymolphthalein as indicator. Enzymatic activity was determined by titration of fatty acid released with $50 \mathrm{mM} \mathrm{NaOH}$. All lipase activity assays were performed at least in triplicate. One unit of lipase was defined as the amount of enzyme that catalyzes the release of $1 \mu \mathrm{mol}$ of fatty acids per minute at $37^{\circ} \mathrm{C}$.

\section{Partial Identification of Fungal Isolates}

Partial identification of fungal isolates was done by visual observation in petri dish culture and micro-morphological studies in slide culture. For visual observation, the isolates grown in PDA were used. The mode of mycelial growth, colour, odour and changes in medium colour of each isolate were examined daily. In the micro- 
morphological studies, a piece of PDA block containing the fungi was detached by a sharp sterile knife. The shape, size, arrangement and development of conidiophores, phialides, conidiospores and phialospores were studied using the taxonomic tools of Hoog et al., (2000).

\section{RESULTS}

Fungi were the only organisms isolated. Bacteria did not grow on the isolation medium. Four genera of fungi belonging to Aspergillus, Penicillium, Trichoderma and Mucor were identified by their macro and micro-morphological characteristics which was the basic identification tool. Aspergillus was the most frequently isolated fungus because it was conspicuously present in all the soil samples analyzed. Penicillium and Trichoderma were present in identical number of samples but Mucor $s p$. was isolated only once. The lipase producing profile of the isolates (Table 1) showed that the highest lipase producing strains belong to the Trichoderma genera while the lowest was Mucor $s p$. The lipase activity of the Aspergillus species was high but varied significantly among the isolates which probably were different species of Aspergillus .

Table 1 - Fungi isolated from different POME dumpsites and their lipase producing activity.

\begin{tabular}{|c|c|c|}
\hline Code & Organism & Lipase activity $(\mathrm{U} / \mathrm{mL})$ \\
\hline PC1a & Aspergillus sp. & 7.54 \\
\hline $\mathrm{PC} 1 \mathrm{~b}$ & Penicillium sp & 6.21 \\
\hline $\mathrm{PC} 1 \mathrm{c}$ & Trichoderma sp. & 8.24 \\
\hline PC1d & Aspergillus sp. & 6.47 \\
\hline $\mathrm{PC} 2 \mathrm{a}$ & Aspergillus sp. & 6.25 \\
\hline $\mathrm{PC} 2 \mathrm{~b}$ & Mucor sp. & 5.72 \\
\hline PC3a & Aspergillus sp. & 7.08 \\
\hline $\mathrm{PC} 3 \mathrm{~b}$ & Trichoderma sp. & 8.07 \\
\hline $\mathrm{PC} 3 \mathrm{c}$ & Penicillium sp. & 5.87 \\
\hline $\mathrm{PC} 4 \mathrm{a}$ & Aspergillus sp. & 7.43 \\
\hline $\mathrm{PC} 4 \mathrm{~b}$ & Penicillium sp. & 6.18 \\
\hline $\mathrm{PC} 4 \mathrm{c}$ & Trichoderma sp. & 7.19 \\
\hline
\end{tabular}

\section{DISCUSSION}

The inability to isolate the bacterial lipase producers did not imply their absence in the POME dumpsites. One factor that could have contributed to the apparent absence of bacterial growth might be associated with the growth conditions prior to sampling. The soil being polluted with oil had very low water activity and low pH (4-5). Fungi, especially moulds are known to adapt best under such environment. The medium of isolation was selective since only organisms capable of metabolizing lipid as carbon and energy source grew on it. Growth and multiplication of microorganisms on any substrate is often considered as the first step towards its bioconversion (Molla et al., 2002). The fungal organisms isolated were identical to those earlier reported by Ibrik et al., (1995); Ugoji (1997); Toida et al., (1998); Namboodiri and Chattopadhaya (2000) and Savitha et al., (2007)

The use of fungal lipases to facilitate processes and application is gaining grounds and so many of them have been characterized (Bapiraju et al., 2004, Prazeres et al., 2006, Kashmiri et al., 2006 and Savitha et al., 2007). In the area of waste water treatment, especially the bioremediation of palm oil mill effluent (POME), the yeast Yarrowia lipolytica have been successfully utilized. (Oswal et al., 2002). Data on lipase producing profile of isolates suggested that the preponderance of Trichoderma and Aspergillus spp in the samples analyzed might not be unconnected with their high lipase producing ability since only organisms capable of metabolizing palm oil as carbon source could grow on the medium of isolation. The variation in enzyme activity level within the Aspergillus genera could be attributable to species differences.

The use of lipases in industries is enormous and increasing. According to Davranov (1994), extensive and persistent screening for new microorganisms and their lipolytic enzyme will open new, simple routes for synthetic processes and consequently new and faster ways to solve environmental problems. 


\section{REFERENCES}

Babu, I.S. and Rao, G.H (2007). Optimization of process parameters for the production of Lipase in submerged fermentation by Yarrowia lipolytica NCIM 3589. Res. J. Microbiol. 2, 88-93.

Bapiraju, K.V.V.S.N., Sujatha, P., Ellaiah, P. and Ramana, T.(2004). Mutation induced enhanced biosynthesis of lipase. Afri. J. of Biotech. 3, 618 - 621.

Burkert, J.F.M., Maugeri, F., Rodrigues, M.I (2004). Optimization of extracellular lipase production by Geotrichum $s p$ using factorial design. Biores. Tech. 91, $77-84$.

Davranov, K. (1994) Microbial lipases in biotechnology, (Review) Appld. Biochem. and Microbiol. 30, 427 432.

Essamri M., Deyris V. and Comeau, L. (1998).Optimization of lipase production by Rhizopus oryzae and study on the stability of lipase activity in organic solvents. J. of Biotech. 60,97-103.

Frost G.M. and Moss D.A. (1987) Production of enzymes by fermentation. In: Rehm H.J. and Reed, G. (eds.,) Biotechnology, Vol 7a Weinheim: Verlag Chemie pp $65-211$.

Ginalska, G., Bancrez, R., and Kornillowicz - Kowalska, T. (2004). A thermostable lipase produced by a newly isolated Geotrichum - like strain, R59. J. Indus. Microbiol. and Biotech. 31, 177 -182.

Hoog, G.S., Guarro, J., Gene, J. and Figueras, M.J. (2000). Hyphomycetes: explanatory chapters and keys to the genera. In: Hoog, G.S., Guarro, J., Gene, J. and Figueras, M.J. (editors). Atlas of Clinical Fungi. $2^{\text {nd }}$ edition. Centraalbureau voor schimmelcultures, Netherlands and Universitat Rovira i Virgili, Spain Press. Pp 361-1008.

Houde, A., Kademi, A., and Leblanc, D. (2004). Lipases and their industrial applications: an overview Appld Biochem. and Biotech. 118, 155 -170.

Ibrik A., Chahinian, H., Rugani, N., Sarda, L., and Comeau, L.C.(1998). Biochemical and structural characterization of triacylglycerol lipase from Penicillium cyclopium. Lipids 33, 377 -384.

Jaeger, K.E. and Reetz, M.T. (1998). Microbial lipases form versatile tools for biotechnology. Tibtech 16, 396 -403 .

Kashmiri, M.A., Adnan, A. and Butt, B.W. (2006).Production, purification and partial characterization of lipase from Trichoderma viride. Afri. J. of Biotech. 5, 878 -882.

Kumar, S., Kikon, K., Upadhyay, A., Kanwar, S.S. and Gupta, R.(2005). Production, purfication and characterization of lipase from thermophilic and alkalophilic Bacillus coagulans BTS - 3. Protein Expr. Purif. 41, 38 -44.

Kyu, R.K., Kwon, D.Y., Yoon, S.H., Kim, W.Y and Kim K.H.(2005). Purificaion, refolding and characterization of recombinant Pseudomonas fluorescens lipase. Protein Expr. and Purif. 39, 124 - 129.
Molla, A.H., Fakhru '1 - Razi, A., Abd- Aziz, S., Hanafi, M.M, Roychoudhury, P.K and Alam M.Z. (2002). A potential resource for bioconversion of domestic waste water sludge. Biores. Tech. 85, 263 -272.

Namboodiri V.M., Chattopadhaya, R. (2000). Purification and characterization of a novel thermostable lipase from Aspergillus niger. Lipids: 35, $495-502$.

Oswal, N., Sarma, P.M., Zinjarde, S.S and Pant, A. (2002). Palm oil mill effluent treatment by a tropical marine yeast. Biores. Tech. 85, 35 -37.

Pandey, A, Benjamin, S., Soccol, C.R. Nigam, P., Kriger, N., Soccol, V.T. (1999). The realm of microbial lipases in biotechnology. Biotechnol. and Appld Biochem. 29, $119-139$.

Pignede, G., Wang, H., Fudalej, F., Gaillardin, C., Seman, M and Nicaud, J (2000). Characterization of an extracellular lipase encoded by LIP2 in Yarrowia lipolytica. J. of Bacterio. 182, 2802 -2810.

Prazeres, J.N., Cruz, J.A.B. and Pastore, G.M. (2006). Characterization of alkaline lipase from Fusarium oxysporum and the effect of different surfactants and detergents on the enzyme activity. Braz J. of Microbiol.. 37, 505 -509.

Rathi, P., Saxena, R.K and Gupta, R.A. (2001). A novel alkaline lipase from Burkholderia cepacia for detergent formulation. Process Biochem 37: 187 -192.

Saeed, H.M., Zaghloul, T.I., Khalil, A.I and Abdelbaeth, M.T. (2005). Purification and characterization of two extracellular lipases from Pseudomonas aeruginosa Ps -x. Pol. J. of Microbiol. 54, 233 -240.

Savitha, J and Ratledge, C. (1991). An inducible, intracellular, alkalophilic lipase in Aspergillus flavipes grown on triglycerols. World J. of Microb. Biotech. 8, $129-131$.

Savitha, J., Srividya, S., Jagat, R., Payal, P., Priyanki, S., Rashmi, G.W., Roshini, K.T.,and Shantala, Y.M. (2007). Identification of potential fungal strain (s) for the production of inducible, extracellular and alkalophilic lipase. Afric. J. of Biotech. 6, 564 -568.

Saxena, R.K., Sheoram, A., Giri, B. and Davidson W.S.(2003). Purification strategies for microbial lipase J. Microbiol Meth. 52, 1-18.

Toida. J., Arikawa,.Y. Kondou, K., Fukuzawa, M and Sekiguchi, J. (1998). Purification and characterization of triacylghycrol lipase from Aspergillus oryzae. Biosci., Biotech. and Biochem. 62, 759 - 763.

Ugoji, E.O. (1997). Anaerobic digestion of palm oil mill effluent and its utilization as fertilizer for environmental protection. Ren. Ener. 10, 291 - 294.

Wiseman, A.(1995).Introduction to principles. In: Wiseman, A (ed.,) Handbook of enzyme biotechnology $3^{\text {rd }}$ edition. Padstow, Cornwall, U.K: Ellis Horwood Ltd., T.J Press Ltd pp 3 -8.

Received: October15, 2009; Revised: February 25, 2010; Accepted: July 28, 2010. 